\title{
The effect of thiamine and its metabolites on peripheral neuropathic pain induced by cisplatin in rats
}

\author{
Didem ONK ${ }^{1)}$, Renad MAMMADOV ${ }^{2)}$, Bahadir SULEYMAN ${ }^{2)}$, Ferda Keskin CIMEN $^{3)}$, \\ Murat CANKAYA ${ }^{4}$, Vahdet GUL ${ }^{5)}$, Durdu ALTUNER ${ }^{2)}$, Onur SENOL ${ }^{6}$, Yucel KADIOGLU6), \\ Ismail MALKOC ${ }^{7)}$, and Halis SULEYMAN ${ }^{2}$ \\ 1) Department of Anesthesiology, Faculty of Medicine, Erzincan University, Başbağlar, Erzincan 24030, Turkey \\ ${ }^{2)}$ Department of Pharmacology, Faculty of Medicine, Erzincan University, Başbağlar, Erzincan 24030, Turkey \\ ${ }^{3)}$ Department of Pathology, Mengucek Gazi Education and Research Hospital, Başbağlar, Erzincan 24100, Turkey \\ 4) Department of Biology, Faculty of Arts and Sciences, Erzincan University, Yalnizbă̆, Erzincan 24030, Turkey \\ ${ }^{5)}$ Department of Psychiatry, Faculty of Medicine, Erzincan University, Başbağlar, Erzincan 24030, Turkey \\ ${ }^{6)}$ Department of Analytical Biochemistry, Faculty of Pharmacy, Ataturk University, Yakutiye, Erzurum 25240, Turkey \\ ${ }^{7)}$ Department of Anatomy Faculty of Medicine, Ataturk University, Yakutiye, Erzurum 25240, Turkey
}

\begin{abstract}
Thiamine pyrophosphate (TPP) is the active metabolite of thiamine. This study aimed to investigate the effects of thiamine and TPP on cisplatin-induced peripheral neuropathic pain (PNP). Male albino Wistar type Rattus norvegicus were divided into six groups $(n=6)$ that received $2 \mathrm{mg} / \mathrm{kg}$ cisplatin (CIS), $25 \mathrm{mg} / \mathrm{kg}$ thiamine (TM), $2 \mathrm{mg} / \mathrm{kg}$ cisplatin $+25 \mathrm{mg} / \mathrm{kg}$ thiamine (CTM), $25 \mathrm{mg} / \mathrm{kg}$ TPP (TPP), $2 \mathrm{mg} / \mathrm{kg}$ cisplatin+25 mg/kg TPP (CTPP), or distilled water (healthy group; HG) for 8 days intraperitoneally. Analgesic effect was measured with a Basile Algesimeter. IL-1 $\beta$, malondialdehyde (MDA), total glutathione (tGSH), thiamine, and TPP were determined in blood samples. Histopathological examinations were performed on removed sciatic nerves. The percent analgesic effects of the CTM and CTPP groups were calculated to be $21.3 \%$ and $82.9 \%$, respectively. Increased production of IL-1 $\beta$ and MDA by cisplatin was inhibited by TPP, while it was not inhibited by thiamine. Conversion of thiamine to TPP significantly decreased in the CIS group. Histopathological and biochemical investigations demonstrated that hyperalgesia and sciatic nerve damage developed in the CIS and CTM groups with low TPP levels. These results indicate that cisplatin inhibits the formation of TPP from thiamine, leading to severe PNP. This finding suggests that TPP may be more beneficial than thiamine for the treatment of cisplatin-induced PNP.
\end{abstract}

Key words: cisplatin, pain, peripheral neuropathy, rat, thiamine.

\section{Introduction}

Pain that is caused by impairment of the peripheral nervous system or impairment of function or sensation has been described by the International Association for the Study of Pain as peripheral neuropathic pain (PNP)
$[5,38]$. PNP is the most common side effect of chemotherapy $[3,8]$, occurring in $80-90 \%$ of the patients undergoing this treatment [19]. This PNP side effect is therefore a serious pathological event that can lead to cessation of chemotherapy treatment; consequently, the treatment and pathogenesis of chemotherapy-induced

(Received 2 August 2017 / Accepted 15 December 2017 / Published online in J-STAGE 12 January 2018)

Address corresponding: H. Suleyman, Department of Pharmacology, Faculty of Medicine, Erzincan University, Başbağlar, Erzincan 24030, Turkey (c) $\odot$ This is an open-access article distributed under the terms of the Creative Commons Attribution Non-Commercial No Derivatives (by-nc-nd) License <http://creativecommons.org/licenses/by-nc-nd/4.0/s.

(C)2018 Japanese Association for Laboratory Animal Science 
PNP are of considerable scientific interest. Chemotherapy-induced PNP models are now used for the discovery of drugs that show fewer side effects and greater effectiveness against PNP.

The platinum-derived anticancer drug cisplatin is a known cause of PNP in animals and has been used to generate an experimental chemotherapy-induced PNP model $[4,7,24]$. The mechanism of chemotherapy-induced PNP is not yet well understood [24], but many studies indicate a role for interleukin-1 $\beta$ (IL-1 $\beta)$ in the formation of PNP [12, 39]. Some studies also suggest that neuropathic pain induced by platinum-derived anticancer drugs is associated with oxidative stress [26]. An association may also exist between cisplatin neurotoxicity and oxidative stress. In this context, thiamine itself has no protective effect, whereas thiamine pyrophosphate (TPP) has a beneficial effect in the treatment of oxidative brain damage induced by cisplatin [35].

Doxorubicin causes TPP deficits in oxidative heart damage by inhibiting the thiamine pyrophosphokinase enzyme, which converts thiamine to TPP in rats. TPP, in turn, is believed to protect cardiac tissue from doxorubicin toxicity [29], and it was thought that there could be a thiamine deficiency in tissue despite there being a normal level in blood [31]. Cisplatin treatment may also lead to oxidative PNP by inhibiting the formation of TPP from thiamine in the body, and TPP may be beneficial in the treatment of cisplatin-induced PNP.

The aim of the study was to investigate the effects of TPP against cisplatin-induced PNP. TPP, an active metabolite of thiamine, is also known as vitamin B1. It is the best indicator of thiamine activity [30] and is formed in the liver by phosphorylation of thiamine by the thiamine pyrophosphokinase enzyme [30, 34]. No evidence has been recorded in the literature to indicate that cisplatin-induced PNP is caused by TPP deficiency. Therefore, the aim of our study was to investigate the effects of thiamine and TPP on cisplatin-induced PNP in rats. The association between the severity of cisplatin-induced PNP and the degree of thiamine deficiency was also further assessed.

\section{Material and Methods}

Animals

Male albino Wistar type Rattus norvegicus were obtained from the Ataturk University Medical Experimental Application and Research Center. The experiment was carried out using a total of 36 rats weighing 235-245 grams. The animals were housed and fed in groups under appropriate conditions at normal room temperature $\left(22^{\circ} \mathrm{C}\right)$ in the Pharmacology Laboratory of Erzincan University for 7 days. Animal experiments were performed in accordance with the National Guidelines for the Use and Care of Laboratory Animals and were approved by the local animal ethics committee of Ataturk University, Erzurum, Turkey (Ethics Committee Number: 7/144, Dated: 04.11.2016).

\section{Chemical substances}

Cisplatin Ebewe, $50 \mathrm{mg} / 100 \mathrm{ml}$ was provided by Liba (Turkey), thiamine and TPP were provided by Biopharma (Russia), and thiopental sodium was obtained from IE Ulagay (Turkey).

\section{Experimental groups}

Rats were divided into six groups: cisplatin CIS; $n=6$, thiamine TM; $n=6$, cisplatin + thiamine CTM; $n=6$, thiamine pyrophosphate TPP: $n=6$, cisplatin + thiamine pyrophosphate CTPP; $\mathrm{n}=6$, and vehicle (distilled water) injected healthy control group HG; $\mathrm{n}=6$.

\section{Experimental procedure}

The normal paw pain thresholds of all rat groups were measured using a Basile Algesimeter before drug administration. The animals were then intraperitoneally (ip) administered $25 \mathrm{mg} / \mathrm{kg}$ of thiamine (CTM and TM groups), $25 \mathrm{mg} / \mathrm{kg}$ TPP (CTPP and TPP groups), or the same volume of distilled water (CIS and HG groups). Five mins after drug administration, $2 \mathrm{mg} / \mathrm{kg}$ cisplatin was administered ip to the CIS, CTM, and CTPP groups. The thiamine, TPP, and distilled water treatments were repeated once a day for 8 days. Cisplatin was administered once every two days for a total of four doses.

After the treatment period, blood samples were taken from the tail veins for analysis of IL- $1 \beta$, malondialdehyde (MDA), total glutathione (tGSH), thiamine, and TPP. The paw pain thresholds of all rat groups were measured in the same way 8 days after drug administration. The analgesic effects of the drugs were determined by comparing the results of each of the CTM, CTPP, and HG groups with those of the CIS group. The percent analgesic effect was calculated using the following formula: analgesic effect $(\%)=(1-\mathrm{D} / \mathrm{C}) \times 100$, where $\mathrm{D}$ represents the difference in the pain threshold for the CTM, CTPP, or HG groups before and after drug admin- 
istration, and $\mathrm{C}$ represents the difference in the pain threshold for the CIS group before and after cisplatin administration [6]. The rats were subsequently killed with a high dose of thiopental sodium, and their sciatic nerves were removed for histopathological examinations.

\section{Biochemical analysis}

Preparation of sera: Blood samples were taken from all rats and collected into separation gel Vacutainer serum tubes. All blood samples were incubated for $15 \mathrm{~min}$ at room temperature, and then the sera were separated by centrifugation at $1500 \times \mathrm{g}$ for $10 \mathrm{~min}$. All serum samples were stored at $-80^{\circ} \mathrm{C}$ until biochemical analysis.

MDA analysis in serum: MDA measurements were based on a previous method involving spectrophotometric measurement of absorbance of the pink-colored complex formed by thiobarbituric acid. The serum sample $(0.1 \mathrm{ml})$ was added to a solution containing $0.2 \mathrm{ml}$ of 80 $\mathrm{g} / 1$ sodium dodecyl sulfate, $1.5 \mathrm{ml}$ of $200 \mathrm{~g} / 1$ acetic acid, $1.5 \mathrm{ml}$ of $8 \mathrm{~g} / 1$ 2-thiobarbiturate, and $0.3 \mathrm{ml}$ distilled water. The mixture was incubated at $95^{\circ} \mathrm{C}$ for $1 \mathrm{~h}$. Upon cooling, $5 \mathrm{ml}$ of n-butanol:pyridine (15:1) was added. The mixture was vortexed for $1 \mathrm{~min}$ and centrifuged for $30 \mathrm{~min}$ at $4000 \mathrm{rpm}$. The absorbance of the supernatant was measured at $532 \mathrm{~nm}$. A standard curve was generated using 1, 1, 3, 3-tetramethoxypropane [27].

Serum tGSH analysis: According to a previously defined method, 5, 5'-dithiobis (2-nitrobenzoic acid) disulfide (DTNB) was used as the chromogen in the medium, as it is reduced easily by sulfhydryl groups. The yellow color produced during reduction was measured spectrophotometrically at $412 \mathrm{~nm}$. For measurement, a cocktail solution was prepared $(5.85 \mathrm{ml} 100 \mathrm{mM}$ Na-phosphate buffer, $2.8 \mathrm{ml} 1 \mathrm{mM}$ DTNB, $3.75 \mathrm{ml} 1 \mathrm{mM} \mathrm{NADPH}$, and $80 \mu 1625 \mathrm{U} / 1$ glutathione reductase). Before measurement, $0.1 \mathrm{ml}$ meta-phosphoric acid was added to $0.1 \mathrm{ml}$ serum and centrifuged for $2 \mathrm{~min}$ at 2,000 rpm to deproteinize the sample. A $0.15 \mathrm{ml}$ volume of cocktail solution was added to $50 \mu$ of the supernatant. A standard curve was generated using GSSG [32].

IL- $1 \beta$ analysis in serum: Serum IL- $1 \beta$ concentrations were measured using a rat-specific sandwich enzymelinked immunosorbent assay (ELISA) rat interleukin $1 \beta$ kit (Cat no: YHB0616Ra, Shanghai LZ) and a rat tumor necrosis factor $\alpha$ ELISA kit (Cat no: YHB1098Ra, Shanghai LZ). Analyses were performed according to the manufacturer's instructions. Briefly, monoclonal antibodies specific for rat IL- $1 \beta$ and TNF- $\alpha$ were coated onto the wells of microplates. The serum samples, standards, and biotinylated specific monoclonal antibodies and streptavidin-HRP were pipetted into the wells and incubated at $37^{\circ} \mathrm{C}$ for $60 \mathrm{~min}$. After washing, chromogen reagent $\mathrm{A}$ and chromogen reagent $\mathrm{B}$ were added to produce a color upon reaction with the bound enzyme. After incubation at $37^{\circ} \mathrm{C}$ for $10 \mathrm{~min}$, a stop solution was added. The intensity of this colored product is directly proportional to the concentration of rat IL- $1 \beta$ present in the original specimen. The concentrations of the colored product in the well plates were read at $450 \mathrm{~nm}$ with a microplate reader (Bio Tek instruments, Inc., Winooski, VT, USA). The absorbance of the samples was estimated with formulas using standard curves.

Measurement of thiamine and TPP levels in serum samples: Whole blood samples were stored at $-80^{\circ} \mathrm{C}$ and then $10 \%$ trichloroacetic acid solution was added at a 1:1 ratio to extract thiamine and TPP. After 5 mins of vortexing and centrifugation at 5,000 rpm for $10 \mathrm{mins}$, the extract was reacted in basic medium containing $\mathrm{K}_{3}(\mathrm{FeCN})_{6}$ and $20 \% \mathrm{NaOH}$ to form thiochromes. The reaction mixture was applied to an HPLC column and separated with mobile phase components, and thiamine and TPP were detected using a fluorescence detector (Agilent Technologies, Waldbronn, Germany) at an excitation wavelength of $375 \mathrm{~nm}$ and emission wavelength of $435 \mathrm{~nm}$. The mobile phases were $74 \% \mathrm{KH}_{2} \mathrm{PO}_{4}$ buffer (pH 6.2) and 26\% methanol. Thiamine and TPP peaks eluted at 7.9 and $2.8 \mathrm{~min}$, respectively.

\section{Histopathological examination}

The removed sciatic nerve tissues of rats were fixed in $10 \%$ formalin solution for $24 \mathrm{~h}$. Sections ( $4 \mu \mathrm{m}$ thick) were obtained from paraffin blocks after routine tissue processing and stained with hematoxylin and eosin. All sections were evaluated under a light microscope (Olympus BX52, Tokyo, Japan) by a pathologist following a blind allocation of samples.

Four-micrometer sections were taken and placed on slides by selecting appropriate blocks. The slides were subjected to alcohol and xylene for $5 \mathrm{~min}$ and deparaffinized in an oven for $20 \mathrm{~min}$. The specimen slides were subjected to immunohistochemical staining using S-100 (Catolog no.: MS-296-R7, Thermo Fisher Scientific, Waltham, MA, USA; 1:100 in antibody diluent). For this, a fully automated immunohistochemical device (BondMax, Leica Biosystems, Melbourne, Australia) was used. After the specimen slides were stained, they were exam- 
Table 1. The effect of thiamine and TPP on the paw pain threshold induced with cisplatin

\begin{tabular}{lrrrr}
\hline & \multicolumn{3}{c}{ Pain threshold values (g) } & \\
\cline { 2 - 4 } Groups & Before drugs & After drugs & $\begin{array}{c}\text { Difference between } \\
\text { before and after drugs }\end{array}$ & $\begin{array}{c}\text { Analgesic } \\
\text { effect (\%) }\end{array}$ \\
\hline CIS & $36.2 \pm 1.3$ & $8 \pm 0.5$ & $28.2 \pm 1.4^{*}$ & - \\
CTM & $33.2 \pm 1.5$ & $11 \pm 1.0$ & $22.2 \pm 2.2^{* *}$ & 21.3 \\
CTPP & $32 \pm 1.1$ & $27.2 \pm 0.9$ & $4.8 \pm 0.4^{* * *}$ & 82.9 \\
HG & $37 \pm 1.5$ & $35.7 \pm 1.4$ & $1.3 \pm 0.2$ & 95.4 \\
TM & $28.3 \pm 1.1$ & $26.8 \pm 0.9$ & $1.5 \pm 0.4$ & 94.7 \\
TPP & $30.2 \pm 1.2$ & $28.8 \pm 1.6$ & $1.3 \pm 0.2$ & 95.4 \\
\hline
\end{tabular}

$* P<0.0001$, compared with HG group. ${ }^{* *} P<0.05$, compared with CIS group. $* * * P<0.0001$, compared with CIS group.

ined with a light microscope (Olympus BX53, Tokyo, Japan).

Four-micrometer sections were taken, placed on lysine slides, and deparaffinized. They were then subjected to tricrome staining (MOS LAB) and examined with a light microscope. The sciatic nerve sections were examined histopathologically by considering the severity of edema, vascular congestion, and fascicular destruction. The severity of the histopathological findings for edema, vascular congestion, and fascicular destruction in each cross-section was scored on a scale of 0 to 3 ( 0 , normal, 1 , mild damage, 2 , moderate damage, and 3 , severe damage).

\section{Statistical analysis}

The results of the biochemical experiments were expressed as the mean $\pm \mathrm{SEM}$, and histopathological findings were expressed as the median (min-max). The significance level among the groups was determined using one-way ANOVA. A Tukey test was performed as a post hoc analysis. For the histopathological findings, comparisons among the groups were performed using a Kruskal-Wallis test, and statistical significance was set as $P<0.05$. In addition, pairs of groups were compared using the Mann-Whitney U test. All statistical procedures were performed using the PASW statistics, version 18. 0 statistical software. A value of $P<0.05$ was accepted as statistically significant.

\section{Results}

\section{Pain test}

Table 1 shows that the paw pain threshold in the CIS group was $28.2 \pm 1.4 \mathrm{~g}$ lower after cisplatin administration than before cisplatin administration $(P<0.0001$, compared with the HG group). The difference in paw pain threshold between before and after drug administration was $22.2 \pm 2.2 \mathrm{~g}$ in the CTM group $(P<0.05$, compared with the CIS group). This indicated that thiamine produced a $21.3 \%$ analgesic effect in animals receiving cisplatin. The difference in paw pain threshold between before and after drug administration was $4.8 \pm 0.4 \mathrm{~g}$ in the CTPP group $(P<0.0001$, compared with the CIS group). This suggests that TPP reduced cisplatin-induced pain by $82.9 \%$. In the HG group, the difference in paw pain threshold between before and after distilled water was $1.3 \pm 0.2 \mathrm{~g}$. Finally, the differences in paw pain threshold between before and after drug administration were $1.5 \pm 0.4 \mathrm{~g}$ and $1.3 \pm 0.2 \mathrm{~g}$ in the TM and TPP groups, respectively $(P<0.0001$, compared with the CIS group).

\section{Biochemical findings}

MDA levels: As shown in Fig. 1A, the MDA level in serum of the HG group was $1.5 \pm 0.2 \mu \mathrm{mol} / \mathrm{g}$ protein. The MDA level in the serum samples of the CIS group was increased $(4.2 \pm 0.2 \mu \mathrm{mol} / \mathrm{g}$ protein; $P<0.0001$, compared with the HG group). The serum level of MDA in the CTM group was $4.6 \pm 0.2 \mu \mathrm{mol} / \mathrm{g}$ protein $(P>0.05$, compared with the CIS group). The serum level of MDA in the CTPP group was $1.8 \pm 0.1 \mu \mathrm{mol} / \mathrm{g}$ protein $(P<0.0001$, compared with the CIS group). Finally the serum levels of MDA in the TM and TPP groups were $1.4 \pm 0.2$ and $1.3 \pm 0.2 \mu \mathrm{mol} / \mathrm{g}$ protein, respectively $(P<0.0001$, compared with the CIS group).

tGSH levels: The tGSH level in serum of the HG group was $7.0 \pm 0.3 \mathrm{nmol} / \mathrm{g}$ protein. However, that in the serum samples of the CIS group rats given cisplatin was $2.1 \pm$ $0.1 \mathrm{nmol} / \mathrm{g}$ protein $(P<0.0001$, compared with the HG group). The serum level of tGSH in the CTM group was 

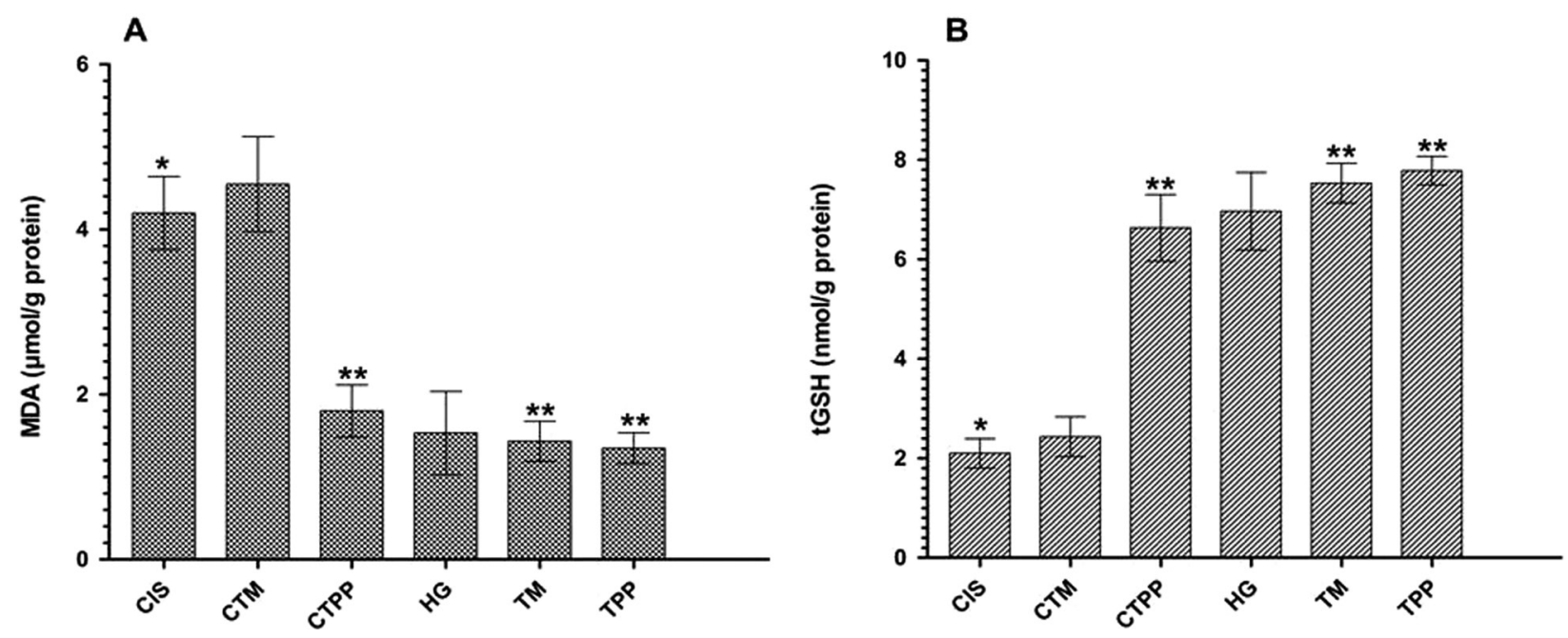

Fig. 1. Serum levels of MDA (A) and tGSH levels (B) in the rat groups ( $\mathrm{n}=6$, for each group). ${ }^{*} P<0.0001$ compared with the HG group. $* * P<0.0001$, compared with the CIS group.

$2.4 \pm 0.2 \mathrm{nmol} / \mathrm{g}$ protein $(P>0.05$, compared with the CIS group). The serum level of tGSH in the CTPP group was $6.6 \pm 0.3 \mathrm{nmol} / \mathrm{g}$ protein $(P<0.0001$, compared with the CIS group). Finally the serum levels of tGSH in the TM and TPP groups were $7.5 \pm 0.4$ and $7.8 \pm 0.3 \mathrm{nmol} / \mathrm{g}$ protein, respectively $(P<0.0001$, compared with the CIS group). (Fig. 1B).

IL- $1 \beta$ levels: The serum IL- $1 \beta$ level in the HG group was $1.7 \pm 0.1 \mathrm{pg} / \mathrm{ml}$, and the level was increased in the CIS group (to $5.3 \pm 0.2 \mathrm{pg} / \mathrm{ml} ; P<0.0001$, compared with the HG group). The serum level of IL- $1 \beta$ in the CTM group was $4.8 \pm 0.3 \mathrm{pg} / \mathrm{ml},(P>0.05$, compared with the CIS group). The serum level of IL- $1 \beta$ in the CTPP group was $2.0 \pm 0.2 \mathrm{pg} / \mathrm{ml}(P<0.0001$, compared with the CIS group). Finally the serum levels of IL- $1 \beta$ in the TM and TPP groups were $1.6 \pm 0.3$ and $1.8 \pm 0.2 \mathrm{pg} / \mathrm{ml}$, respectively ( $P<0.0001$, compared with the CIS group) (Fig. 2).

The thiamine and TPP levels in serum: The serum thiamine level was higher in the CTM group than in the CIS group $(P<0.001)$. No significant difference was noted in the thiamine levels in the serum samples of the CTPP and HG groups $(P>0.05$, compared with the CIS group). The serum thiamine levels were higher in the $\mathrm{TM}(P<0.0001)$ group than in the CIS group. The serum thiamine levels were increased in the TPP group compared with the CIS group, but the difference was not statistically significant $(P=0.122)$ (Fig. 3A). However, cisplatin caused a decrease in TPP in the serum of the CIS group animals $(P<0.0001$, compared with the HG

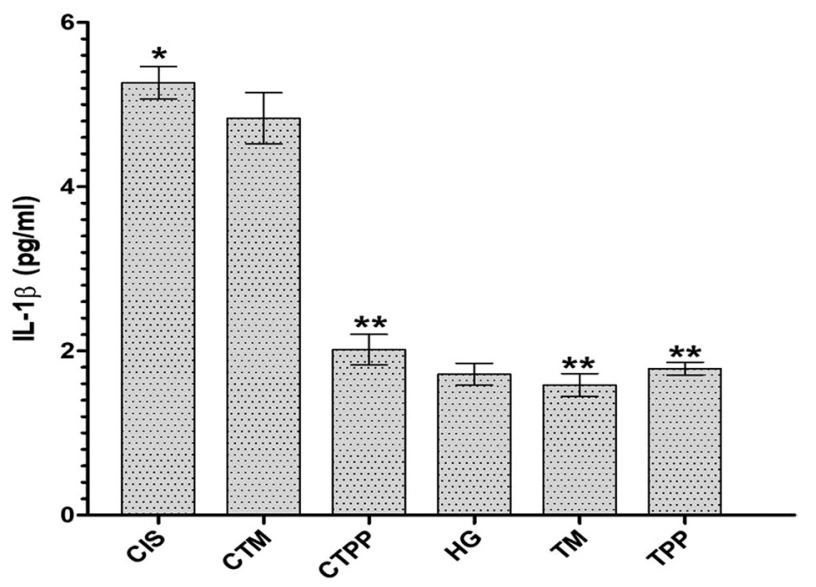

Fig. 2. Serum IL-1 $\beta$ levels in the rat groups ( $\mathrm{n}=6$, for each group). $* P<0.0001$, compared with the HG group. $* * P<0.0001$, compared with the CIS group.

group), whereas the TPP level was increased in the sera of the CTPP groups rats $(P<0.0001$, compared with the CIS group). Finally the serum TPP levels were higher in the TM and TPP groups than in the CIS group $(P<0.0001)$ (Fig. 3B).

\section{Histopathological findings}

Histopathological examination of sciatic nerve tissue of HG, TM, and TPP rat groups resulted in grades of 0 for the histopathological variables, i.e., edema, vasculer congestion, and fascicular destruction (Table 2, Figs. 4A-C). In the CIS group, damage of the sciatic nerve, i.e., edema, vascular congestion, and fascicular destruc- 

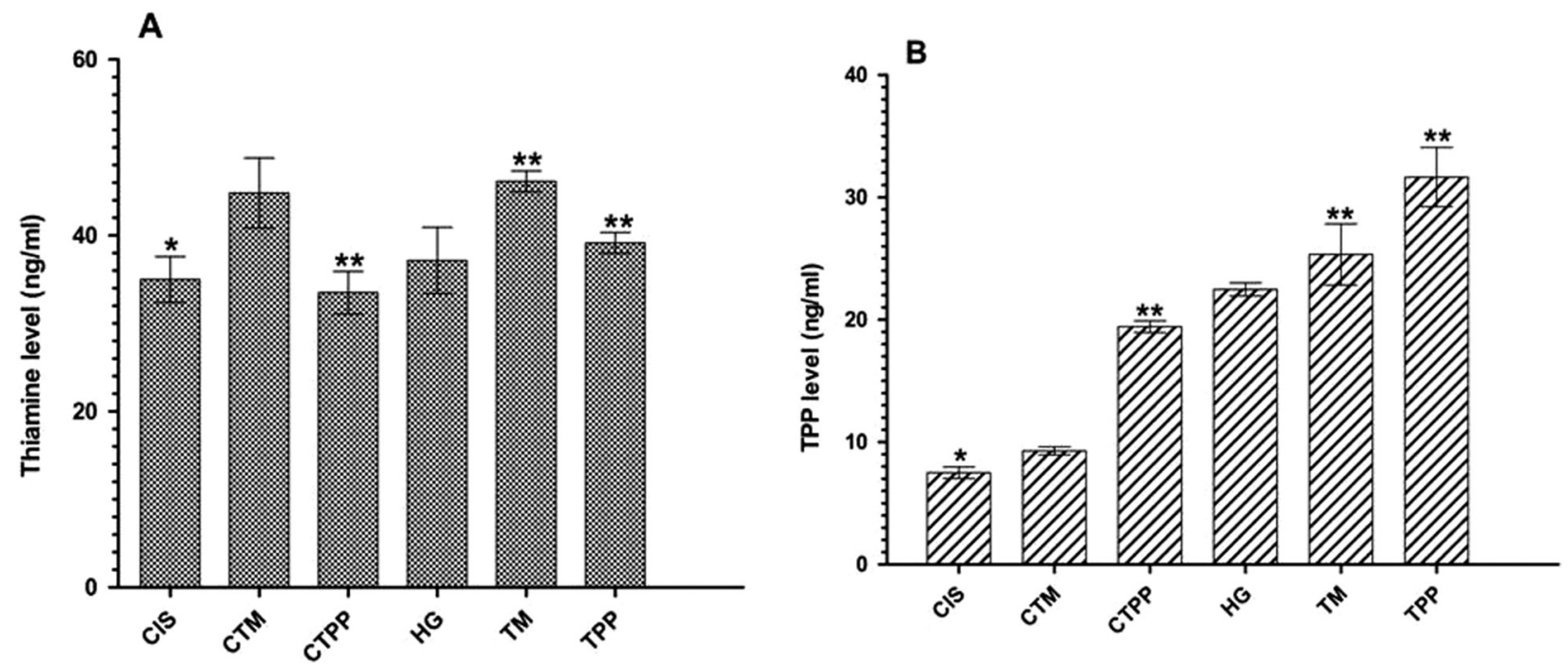

Fig. 3. Serum thiamine (A) and TPP (B) levels in the rat groups ( $\mathrm{n}=6$, for each group). ${ }^{*} P<0.0001$, compared with the HG group. $* * P<0.0001$, compared with the CIS group.

Table 2. The effect of thiamine and TPP on histopathological damage induced with cisplatin

\begin{tabular}{lcccccc}
\hline \multirow{2}{*}{ Variables } & \multicolumn{7}{c}{ Groups } \\
\cline { 2 - 7 } & CIS & CTM & CTPP & HG & TM & TPP \\
\hline Edema & $3(3-3)^{*}$ & $3(2-3)$ & $1(1-2)^{* *}$ & $0(0-0)$ & $0(0-0)^{* *}$ & $0(0-0)^{* *}$ \\
Vascular congestion & $3(2-3)^{*}$ & $3(2-3)$ & $0(0-0)^{* *}$ & $0(0-0)$ & $0(0-0)^{* *}$ & $0(0-0)^{* *}$ \\
Fascicular destruction & $3(2-3)^{*}$ & $2,5(1-3)$ & $0(0-0)^{* *}$ & $0(0-0)$ & $0(0-0)^{* *}$ & $0(0-0)^{* *}$ \\
\hline
\end{tabular}

Data are presented as the median (min-max). The $P$-values represent Mann-Whitney U test results. $* P<0.001$, compared with HG group. $* * P<0.001$, compared with CIS group.

tion was evaluated as grade-3 (Figs. 5A, B and Table 2). The histopathological damage in the sciatic nerve fascicles of the CIS group was also confirmed by S-100 (Fig. 5C) and trichrome staining (Fig. 5D). Pathological findings were evaluated as severe in all tissue sections of the CIS group. Sciatic nerve tissue damage in the CTM group was evaluated as grade 3 for edema and vascular congestion and grade 2.5 for fascicular destruction (Table 2, Fig. 6). Histopathologic damage was evaluated as grade- 1 for edema, grade 0 for vasculer congestion, and grade 0 for fascicular destruction in sciatic nerve tissue of the CTPP group (Fig. 7). The use of thiamine in the CTPP group significantly reduced the histopathological findings for vascular congestion and fascicular destruction compared with the CIS group $(P<0.0001)$ (Table 2).

\section{Discussion}

This study investigated the effects of thiamine and TPP on cisplatin-induced PNP in rats. We also investigated whether cisplatin-induced PNP correlates with serum thiamine and TPP deficiency. Our experimental results showed that cisplatin reduced the paw pain threshold in the HG, CTM, and TPP groups; however, the analgesic effect in the CTM group was very low compared with the CTPP group. In the literature, reduction in the pain threshold is considered to represent hyperalgesia, whereas elevation indicates analgesia [20].

PNP is one of the most common side effects of chemotherapy. For this reason, chemotherapy-induced PNP models have gained importance when they are directed toward the prevention of the side effects of cancer drugs. In recent years, the paw withdrawal test has been widely used as a method of pain evaluation $[2,20]$. In particular, the reason for choosing the paw withdrawal test 


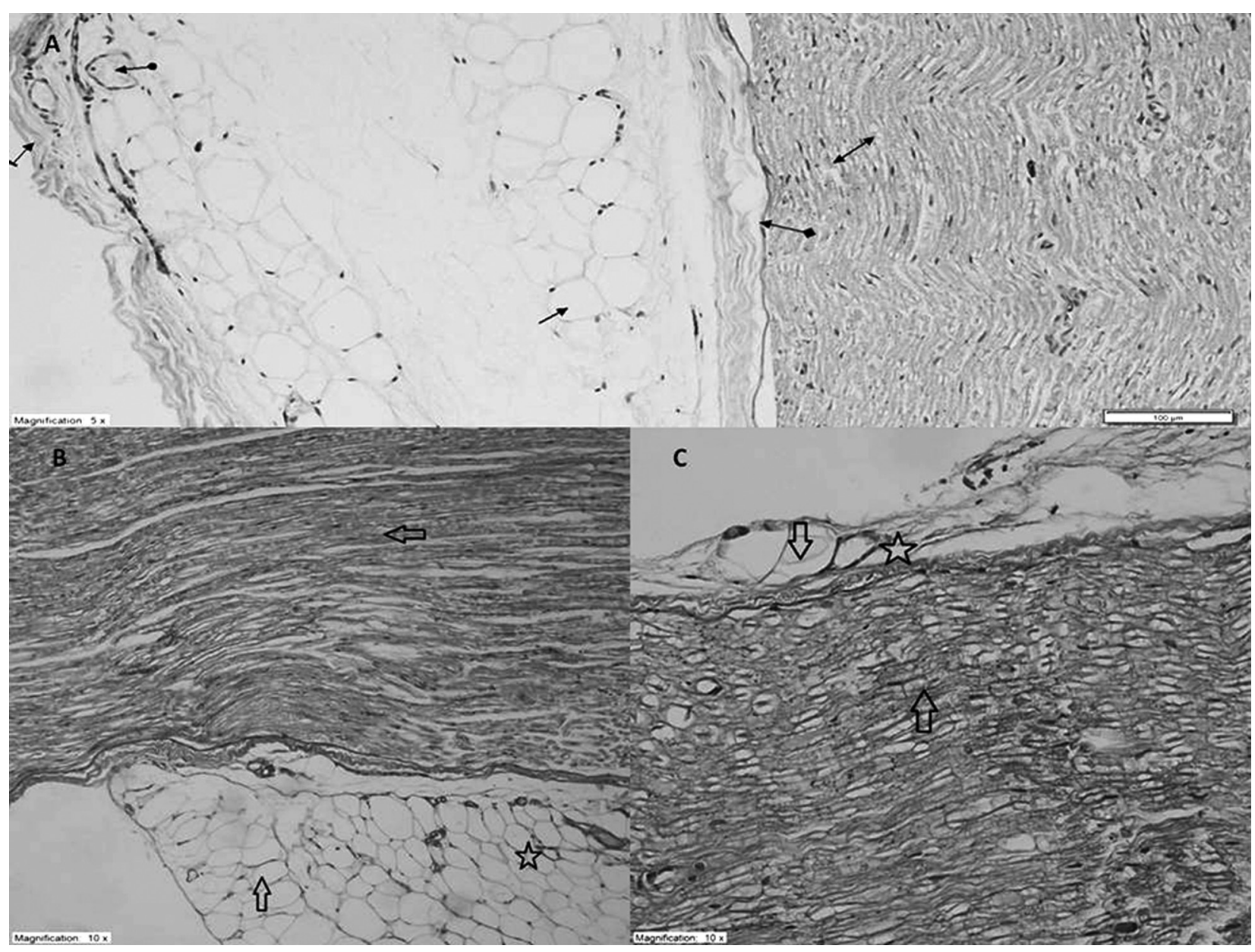

Fig. 4. Normal structures of the sciatic nerve, epineurium (line arrow), vessels (circle arrow), adipose tissue (smooth arrow), perineurium (square arrow), and nerve fascicles (bilateral arrow) in the $\mathrm{HG}$ (A) and epineurium (arrow), blood vessels in the epineurium (star) and nerve fascicles (arrow) TM (B) and TPP (C) rat groups ( $\mathrm{n}=6$, for each group) (scale bar=100 $\mu \mathrm{m})$.

to assess chemotherapy-induced PNP is that neuropathic pain first appears in this region [28]. The paw withdrawal test is also used to generate experimental PNP with cisplatin [25]. Our results suggest that TPP is more effective than thiamine in decreasing pain associated with cisplatin in rat paws.

Cisplatin, which reduced the threshold of paw pain, increased the amount of MDA in the serum of the animals and decreased the amount of tGSH. MDA is used to estimate lipid peroxidation, and tGSH is used for determination of antioxidant activity [11]. Increases in MDA were reported in the cisplatin-induced peripheral neurotoxicity model, whereas tGSH levels were decreased [33]. Recent studies have also suggested a significant link between pain/analgesia and oxidant/antioxidant parameters [2,9]. In the present study, increased amounts of IL- $1 \beta$ and MDA and a decreased amount of
tGSH were observed in the blood serum of the rats given cisplatin.

Previous studies have also suggested that IL- $1 \beta$ plays a role in the development of painful peripheral neuropathy [37].

Chemotherapy-induced PNP is associated with increased IL-1 $\beta$ [17]. Stimulation of IL- $1 \beta$ in the spinal dorsal horn also plays a critical role in the development of painful peripheral neuropathy [23]. This finding supports our experimental results with cisplatin.

In this study, we observed that thiamine did not prevent the increase in MDA and IL- $1 \beta$ or the decrease in tGSH induced by cisplatin, but TPP did prevent these responses. However, these effects of thiamine and TPP on chemotherapy-induced PNP were not found in some other studies. Some reports indicate that TPP protects tissues from oxidative damage. TPP inhibits the increase 


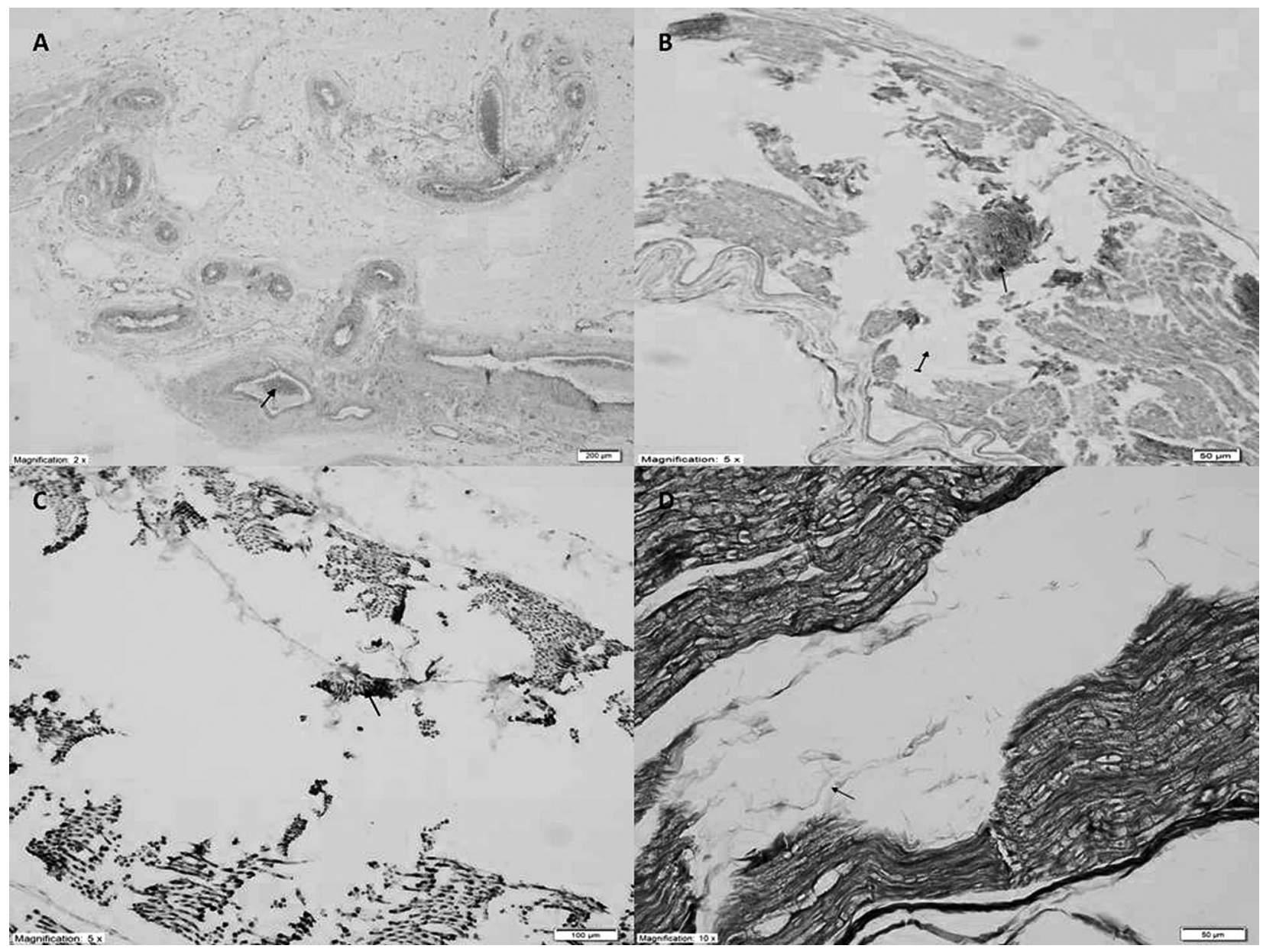

Fig. 5. A: Vascular congestion in the epineurium layer of the sciatic nerve tissue in the CIS rat group. B: Destruction and edema in the nerve fascicles of the CIS rat group. C: Fascicular destruction determined by S-100 staining of the sciatic nerve in the CIS rat group. D: Fascicular destruction determined by trichrome staining of the sciatic nerve in the CIS rat group.

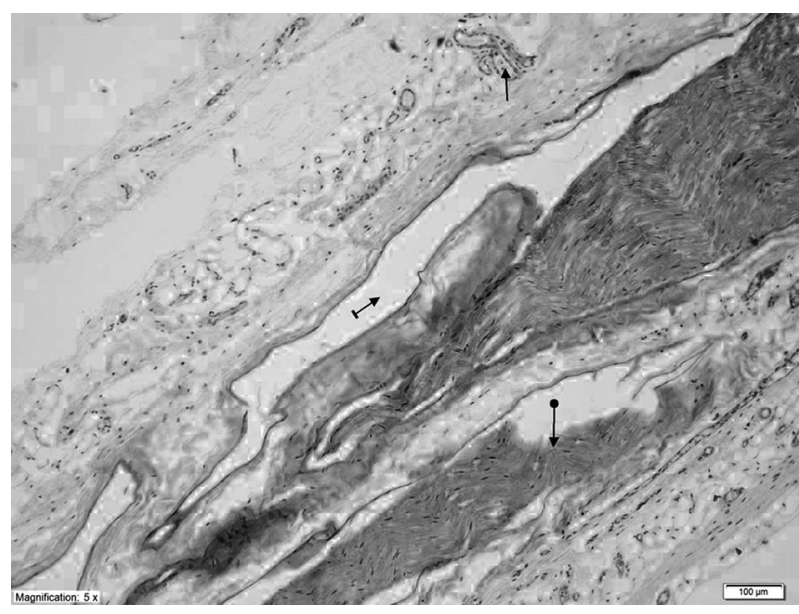

Fig. 6. Fascicular destruction (round arrow), edema (line arrow), and vascular congestion (smooth arrow) structure in the CTM rat group ( $\mathrm{n}=6$, for each group).

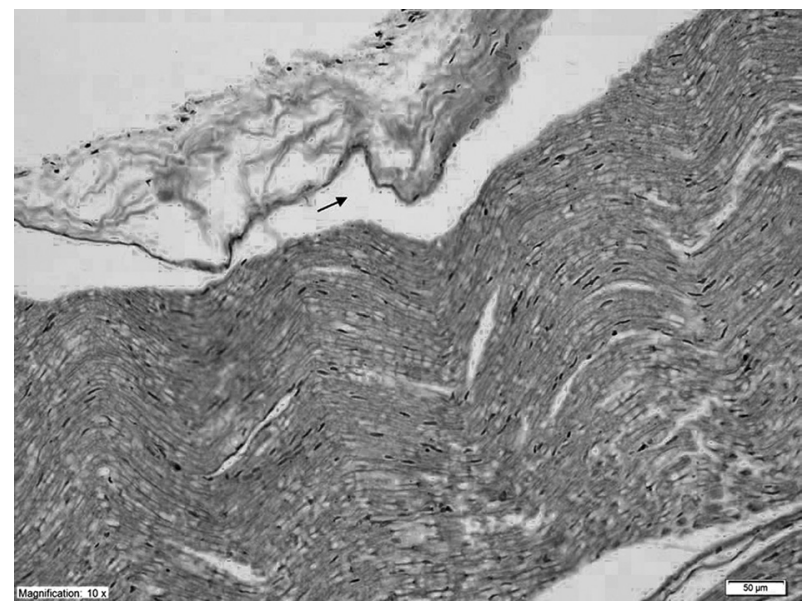

Fig. 7. Edema (straight arrow) in sciatic nerve tissue of the CTPP rat group ( $\mathrm{n}=6$, for each group). 
in MDA and the decrease in tGSH induced by chemotherapeutic drugs in the liver [14]. TPP was effective at inhibiting cisplatin-induced oxidative damage in kidney tissue, whereas thiamine was ineffective [36]. TPP also has an inhibitory effect on proinflammatory IL- $1 \beta$, as well as antioxidant activity [10]. This finding is compatible with literature reports showing that TPP, but not thiamine is able to maintain the levels of serum MDA, IL- $1 \beta$, and tGSH at physiological levels in rats receiving cisplatin.

The CTPP group had a high paw pain threshold and high tGSH levels, whereas the MDA and IL- $1 \beta$ levels were low, and the serum TPP levels were close to those of the HG group. This suggests that cisplatin may inhibit the in vivo formation of TPP from thiamine and give rise to PNP. Other studies also support this hypothesis; for example, the use of doxorubicin in chemotherapy prevented the formation of TPP, which is the active form of thiamine [29], in agreement with an earlier study [18]. TPP is a known cofactor of the transketolase enzyme that participates in the synthesis of natural antioxidants such as NADPH and GSH. TPP may therefore play a very important role in energy production in the heart, muscles, and brain and in the vision and nervous systems [13, 16, 22].

Thiamine was insignificantly higher in the TPP group than in the CIS group, and this may have been due to exogenous TPP reducing the need for conversion of endogenous thiamine to TPP. Our study also showed histopathological findings that were consistent with the biochemical results. No histopathological damage was found in the sciatic nerve in the HG, TM, and TPP group animals. The histopathological examinations revealed edema, vascular congestion, and fascicular destruction in the CIS and CTM groups, which also contained high levels of MDA and IL-1 $\beta$ and low levels of tGSH. However, only edema was observed in the CTPP group, which had low levels of MDA and IL-1 $\beta$ and high levels of tGSH.

Numerous studies that have investigated cisplatin effects support our histopathological findings in the sciatic nerve tissue. For example, cisplatin caused destructive damage to the sciatic nerve [21] and was reported to cause pathological changes, such as sciatic axonal degeneration, axonal connective tissue loss, and edema [15]. Furthermore a high amount of serum MDA and low amount of tGSH were observed in the cisplatin-induced neurotoxicity model [1].

\section{Conclusions}

Biochemical and histopathological studies on cisplatin confirmed that it produces oxidative stress in the sciatic nerve tissue of rats. TPP is more effective than thiamine against cisplatin-induced PNP. The fact that the effect of thiamine is lower than TPP suggests that the cisplatin effects may involve inhibition of the formation of TPP from thiamine. Therefore, administration of TPP may be more beneficial than thiamine as a treatment for cisplatin-induced PNP.

\section{References}

1. Akman, T., Akman, L., Erbas, O., Terek, M.C., Taskiran, D., and Ozsaran, A. 2015. The preventive effect of oxytocin to Cisplatin-induced neurotoxicity: an experimental rat model. BioMed Res. Int. 2015: 167235. [Medline] [CrossRef]

2. Aksoy, M., Ahiskalioglu, A., Ince, I., Celik, M., Dostbil, A., Kuyrukluyildiz, U., Altuner, D., Kurt, N., and Suleyman, H. 2015. The relation between the effect of a subhypnotic dose of thiopental on claw pain threshold in rats and adrenalin, noradrenalin and dopamine levels. Exp. Anim. 64: 391-396. [Medline] [CrossRef]

3. Aley, K.O., Reichling, D.B., and Levine, J.D. 1996. Vincristine hyperalgesia in the rat: a model of painful vincristine neuropathy in humans. Neuroscience 73: 259-265. [Medline] [CrossRef]

4. Authier, N., Fialip, J., Eschalier, A., and Coudoré, F. 2000. Assessment of allodynia and hyperalgesia after cisplatin administration to rats. Neurosci. Lett. 291: 73-76. [Medline] [CrossRef]

5. Beydoun, A. 2003. Neuropathic pain: from mechanisms to treatment strategies. J. Pain Symptom Manage. 25:(Suppl): S1-S3. [Medline] [CrossRef]

6. Cadirci, E., Suleyman, H., Hacimuftuoglu, A., Halici, Z., and Akcay, F. 2010. Indirect role of $\beta 2$-adrenergic receptors in the mechanism of analgesic action of nonsteroidal antiinflammatory drugs. Crit. Care Med. 38: 1860-1867. [Medline] [CrossRef]

7. Cavaletti, G., Petruccioli, M.G., Tredici, G., Marmiroli, P., Barajon, I., Fabbrica, D., and Di Francesco, A. 1991. Effects of repeated administration of low doses of cisplatin on the rat nervous system. Int. J. Tissue React. 13: 151-157. [Medline]

8. Cavaletti, G., Tredici, G., Braga, M., and Tazzari, S. 1995. Experimental peripheral neuropathy induced in adult rats by repeated intraperitoneal administration of taxol. Exp. Neurol. 133: 64-72. [Medline] [CrossRef]

9. Cetin, N., Suleyman, B., Kuyrukluyildiz, U., Nalkiran, H.S., Kiran, A., Gencoglu, S., Duzgun, A., Kurtoglu, I.Z., Yarali, O., Gul, M.A., and Suleyman, H. 2016. Investigation of mucus obtained from different fish species on the acute pain induced with scalpel incision in paw of rats. Exp. Anim. 65: 77-85. [Medline] [CrossRef]

10. Cinici, E., Mammadov, R., Findik, H., Suleyman, B., Cetin, 
N., Calik, I., Balta, H., Tas, I.H., Sener, E., and Altuner, D. The protective effect of thiamine pyrophosphate against sugar-induced retinal neovascularisation in rats. Int. J. Vitam. Nutr. Res. (in press).

11. Coskun, A.K., Yigiter, M., Oral, A., Odabasoglu, F., Halici, Z., Mentes, O., Cadirci, E., Atalay, F., and Suleyman, H. 2011. The effects of montelukast on antioxidant enzymes and proinflammatory cytokines on the heart, liver, lungs, and kidneys in a rat model of cecal ligation and puncture-induced sepsis. Sci. World J. 11: 1341-1356. [Medline] [CrossRef]

12. Costa, G.M.F., de Oliveira, A.P., Martinelli, P.M., da Silva Camargos, E.R., Arantes, R.M.E., and de Almeida-Leite, C.M. 2016. Demyelination/remyelination and expression of interleukin- $1 \beta$, substance $\mathrm{P}$, nerve growth factor, and glial-derived neurotrophic factor during trigeminal neuropathic pain in rats. Neurosci. Lett. 612: 210-218. [Medline] [CrossRef]

13. Lima, L.F., Leite, H.P., and Taddei, J.A. 2011. Low blood thiamine concentrations in children upon admission to the intensive care unit: risk factors and prognostic significance. Am. J. Clin. Nutr. 93: 57-61. [Medline] [CrossRef]

14. Demiryilmaz, I., Sener, E., Cetin, N., Altuner, D., Suleyman, B., Albayrak, F., Akcay, F., and Suleyman, H. 2012. Biochemically and histopathologically comparative review of thiamine's and thiamine pyrophosphate's oxidative stress effects generated with methotrexate in rat liver. Med. Sci. Monit. 18: BR475-BR481. [Medline] [CrossRef]

15. Erken, H.A., Koç, E.R., Yazıcı, H., Yay, A., Önder, G.Ö., and Sarıc1, S.F. 2014. Selenium partially prevents cisplatininduced neurotoxicity: a preliminary study. Neurotoxicology 42: 71-75. [Medline] [CrossRef]

16. Gangolf, M., Czerniecki, J., Radermecker, M., Detry, O., Nisolle, M., Jouan, C., Martin, D., Chantraine, F., Lakaye, B., Wins, P., Grisar, T., and Bettendorff, L. 2010. Thiamine status in humans and content of phosphorylated thiamine derivatives in biopsies and cultured cells. PLoS One 5: e13616. [Medline] [CrossRef]

17. Guindon, J., Deng, L., Fan, B., Wager-Miller, J., and Hohmann, A.G. 2014. Optimization of a cisplatin model of chemotherapy-induced peripheral neuropathy in mice: use of vitamin $\mathrm{C}$ and sodium bicarbonate pretreatments to reduce nephrotoxicity and improve animal health status. Mol. Pain 10: 56. [Medline] [CrossRef]

18. Hanninen, S.A., Darling, P.B., Sole, M.J., Barr, A., and Keith, M.E. 2006. The prevalence of thiamin deficiency in hospitalized patients with congestive heart failure. J. Am. Coll. Cardiol. 47: 354-361. [Medline] [CrossRef]

19. Hoke, A. 2012. Animal models of peripheral neuropathies. The journal of the American Society for Experimental NeuroTherapeutics. Neurol. Ther. 9: 262-269.

20. Ince, I., Aksoy, M., Ahiskalioglu, A., Comez, M., Dostbil, A., Celik, M., Yilmaz, I., Mammadov, R., Dogan, H., Boztok Ozgermen, B., and Altuner, D. 2015. A Comparative Investigation of the Analgesic Effects of Metamizole and Paracetamol in Rats. J. Invest. Surg. 28: 173-180. [Medline] [CrossRef]

21. Kamisli, S., Ciftci, O., Kaya, K., Cetin, A., Kamisli, O., and Ozcan, C. 2015. Hesperidin protects brain and sciatic nerve tissues against cisplatin-induced oxidative, histological and electromyographical side effects in rats. Toxicol. Ind. Health 31: 841-851. [Medline] [CrossRef]

22. Kopelman, M.D., Thomson, A.D., Guerrini, I., and Marshall, E.J. 2009. The Korsakoff syndrome: clinical aspects, psychology and treatment. Alcohol Alcohol. 44: 148-154. [Medline] [CrossRef]

23. Li, Z.Y., Zhang, Y.P., Zhang, J., Zhang, S.B., Li, D., Huang, Z.Z., and Xin, W.J. 2016. The possible involvement of JNK activation in the spinal dorsal horn in bortezomib-induced allodynia: the role of TNF- $\alpha$ and IL-1 $\beta$. J. Anesth. 30: 55-63. [Medline] [CrossRef]

24. Lin, H., Heo, B.H., and Yoon, M.H. 2015. A New Rat Model of Cisplatin-induced Neuropathic Pain. Korean J. Pain 28: 236-243. [Medline] [CrossRef]

25. Naji-Esfahani, H., Vaseghi, G., Safaeian, L., Pilehvarian, A.A., Abed, A., and Rafieian-Kopaei, M. 2016. Gender differences in a mouse model of chemotherapy-induced neuropathic pain. Lab. Anim. 50: 15-20. [Medline] [CrossRef]

26. Nassini, R., Gees, M., Harrison, S., De Siena, G., Materazzi, S., Moretto, N., Failli, P., Preti, D., Marchetti, N., Cavazzini, A., Mancini, F., Pedretti, P., Nilius, B., Patacchini, R., and Geppetti, P. 2011. Oxaliplatin elicits mechanical and cold allodynia in rodents via TRPA1 receptor stimulation. Pain 152: 1621-1631. [Medline] [CrossRef]

27. Ohkawa, H., Ohishi, N., and Yagi, K. 1979. Assay for lipid peroxides in animal tissues by thiobarbituric acid reaction. Anal. Biochem. 95: 351-358. [Medline] [CrossRef]

28. Perry, M.C. 2008. The chemotherapy source book: Lippincott Williams \& Wilkins.

29. Polat, B., Suleyman, H., Sener, E., and Akcay, F. 2015. Examination of the effects of thiamine and thiamine pyrophosphate on Doxorubicin-induced experimental cardiotoxicity. J. Cardiovasc. Pharmacol. Ther. 20: 221-229. [Medline] [CrossRef]

30. Rindi, G., Patrini, C., Laforenza, U., Mandel, H., Berant, M., Viana, M.B., Poggi, V., and Zarra, A.N. 1994. Further studies on erythrocyte thiamin transport and phosphorylation in seven patients with thiamin-responsive megaloblastic anaemia. J. Inherit. Metab. Dis. 17: 667-677. [Medline] [CrossRef]

31. Sasaki, T., Yukizane, T., Atsuta, H., Ishikawa, H., Yoshiike, T., Takeuchi, T., Oshima, K., Yamamoto, N., Kurumaji, A., and Nishikawa, T. 2010. [A case of thiamine deficiency with psychotic symptoms--blood concentration of thiamine and response to therapy]. Seishin Shinkeigaku Zasshi 112: 97110.(in Japanese) [Medline]

32. Sedlak, J. and Lindsay, R.H. 1968. Estimation of total, protein-bound, and nonprotein sulfhydryl groups in tissue with Ellman's reagent. Anal. Biochem. 25: 192-205. [Medline] [CrossRef]

33. Sharawy, N., Rashed, L., and Youakim, M.F. 2015. Evaluation of multi-neuroprotective effects of erythropoietin using cisplatin induced peripheral neurotoxicity model. Exp. Toxicol. Pathol. 67: 315-322. [Medline] [CrossRef]

34. Sica, D.A. 2007. Loop diuretic therapy, thiamine balance, and heart failure. Congest. Heart Fail. 13: 244-247. [Medline] [CrossRef]

35. Turan, M.I., Cayir, A., Cetin, N., Suleyman, H., Siltelioglu Turan, I., and Tan, H. 2014. An investigation of the effect 
of thiamine pyrophosphate on cisplatin-induced oxidative stress and DNA damage in rat brain tissue compared with thiamine: thiamine and thiamine pyrophosphate effects on cisplatin neurotoxicity. Hum. Exp. Toxicol. 33: 14-21. [Medline] [CrossRef]

36. Turan, M.I., Siltelioglu Turan, I., Mammadov, R., Altınkaynak, K., and Kisaoglu, A. 2013. The effect of thiamine and thiamine pyrophosphate on oxidative liver damage induced in rats with cisplatin. BioMed Res. Int. 2013: 783809. [Medline] [CrossRef]

37. Watkins, L.R. and Maier, S.F. 2003. Glia: a novel drug dis- covery target for clinical pain. Nat. Rev. Drug Discov. 2: 973-985. [Medline] [CrossRef]

38. White, S. 2004. Assessment of chronic neuropathic pain and the use of pain tools. Br. J. Nurs. 13: 372-378. [Medline] [CrossRef]

39. Whitehead, K.J., Smith, C.G., Delaney, S.A., Curnow, S.J., Salmon, M., Hughes, J.P., and Chessell, I.P. 2010. Dynamic regulation of spinal pro-inflammatory cytokine release in the rat in vivo following peripheral nerve injury. Brain Behav. Immun. 24: 569-576. [Medline] [CrossRef] 